\title{
Congenital hepatic fibrosis associated with ascites in a nellore calf
}

\author{
Daniela Dantas de Gois ${ }^{1}$ Isabelle Vieira de Sousa ${ }^{1}$ Francisca Maria Sousa Barbosa $^{1}$ (D) \\ José Ferreira da Silva Neto ${ }^{1}$ Rubia Avlade Guedes Sampaio ${ }^{1}$ (D) Sara Vilar Dantas Simões ${ }^{1}$ \\ Igor Mariz Dantas ${ }^{1}$ Ricardo Barbosa Lucena ${ }^{1^{*}}$ iD
}

${ }^{1}$ Hospital Veterinário, Universidade Federal da Paraíba (UFPB), 58397-000, Areia, PB, Brasil. E-mail: lucena.rb@gmail.com. "Corresponding author.

ABSTRACT: Congenital hepatic fibrosis (CHF) is an autosomal recessive malformation characterized by a variable degree of fibrosis and bile duct proliferation, mainly described in people and rarely reported in bovine European breeds. In addition to liver fibrosis, this syndrome has been associated with ascites and subcutaneous edema in calves. This paper described the pathological findings of the first report of CHF in a Nelore bovine fetus. A stillborn calf was removed by cesarean section because of dystocia. At necropsy, characteristic changes of CHF were observed, such as a large increase in abdominal volume associated with hepatic fibrosis and marked subcutaneous edema. Histological examination of liver revealed periportal and port-portal islands of fibrosis separating the parenchyma into nodules of variable sizes and containing numerous abnormally shaped bile ducts. The CHF should be considered in the differential diagnosis in young calves that present with ascites.

Key words: Bos primigenius indicus, genetic factors, malformation, perinatal mortality.

Fibrose hepática congênita associada à ascite em um bezerro nelore

RESUMO: A fibrose hepática congênita (FHC) é uma malformação autossômica recessiva, caracterizada por um variável grau de fibrose e proliferação de ductos biliares, descrita principalmente em pessoas, e raramente relatada em bovinos de raças europeias. Além da fibrose hepática em bezerros, esta síndrome tem sido associada à ascite e edema subcutâneo. O presente trabalho apresenta os achados anatomopatológicos do primeiro relato de FHC em um feto bovino da raça nelore. O bezerro natimorto foi retirado por meio de cesariana devido à distocia. Na necropsia foram verificadas alterações características da FHC, como grande aumento de volume abdominal associado à fibrose hepática e marcado edema subcutâneo. O exame histológico do figado revelou ilhas de fibrose periportal e porto-portal, separando o parênquima em nódulos de tamanhos variáveis e contendo numerosos ductos biliares irregulares de tamanhos anormais.

Palavras-chave: Bos primigenius indicus, fatores genéticos, malformação, mortalidade perinatal.

Congenital liver fibrosis (FHC) is a rare genetic disorder, described in children and calves, which is characterized by marked fibrosis of the liver parenchyma (INDART et al., 2019), usually associated with increased abdominal volume and subcutaneous edema (BOURQUE et al., 2001). The abdominal distension results from the accumulation of cloudy ascitic fluid that varies from yellowish to reddish. This liquid can also be seen inside the thoracic cavity and pericardial sac (TESTONI et al., 2009).

Liver fibrosis can be accompanied by malformations in the atria, interventricular septum, and persistent ductus arteriosus (HARPER et al., 1998; TESTONI et al., 2009). Polycystic kidneys and dilated ureters are observed, visibly enlarged (TESTONI et al., 2009; BOURQUE et al., 2001). Other malformations that accompany CHF include deformities in the face, limbs, and spine. The face may be shortened, flattened, and enlarged, which is similar to a change called a calf with a "bulldog aspect" (AGERHOLM et al., 2004). Malformations such as cleft palate, shortening of the tongue, changes in the shape of the splanchnocranium and absence of sesamoids in the affected limbs have been reported (TESTONI et al., 2009). 
The diagnosis of congenital fibrosis of the liver is confirmed by necropsy findings, in addition to histopathological evaluation, in which there is marked fibrosis of the liver parenchyma, associated with the proliferation of bile ducts (MOVASSAGHI et al., 2011). Masson's trichrome (MT) staining should be performed to show the degree of fibrosis (BOURQUE et al., 2001; TESTONI et al., 2009). The present report aimed to describe the macroscopic and histopathological aspects of hepatic fibrosis and ascites in a Nellore bovine fetus.

A bovine, male, Nellore, stillborn, product of fixed-time artificial insemination, was sent for necropsy with a history of dystocia lasting $18 \mathrm{~h}$. The calf was removed by cesarean section on a farm in the municipality of Cacimba de Dentro, Paraíba, Brazil. The herd consisted of 30 Nellore cows raised in an extensive system in an area of native vegetation. All cows were subjected to artificial insemination, but only this cow presented dystocia.

Necropsy was performed, and multiple organ fragments were collected. Samples were fixed in $10 \%$ buffered formaldehyde, processed routinely for histological examination, and embedded into paraffin blocks. Sections of the organs were cut to 4 $\mu \mathrm{m}$, and stained with hematoxylin and eosin (HE) and MT, and examined histologically.

Macroscopically, significant changes were noted in the abdomen, limbs, and face (Figure 1A). The main macroscopic change present in the calf was an enlarged fluid-filled abdomen (ascites). The face was slightly shortened. The ocular, oral, and anal mucous membranes were blue and interpreted as cyanosis. The four limbs had permanent hyperextension, in addition to swelling, interpreted as edema.

When cutting the skin, the subcutaneous tissue presented marked diffuse edema composed of reddish liquid (Figure 1B). In the peritoneum, a large amount of red and cloudy liquid was noted. This liquid was mainly accumulated in the middle of the omentum and mesentery (Figure 1C). Upon cutting, the omentum wall was markedly thickened because of liquid deposition (Figure 1D). There was also an

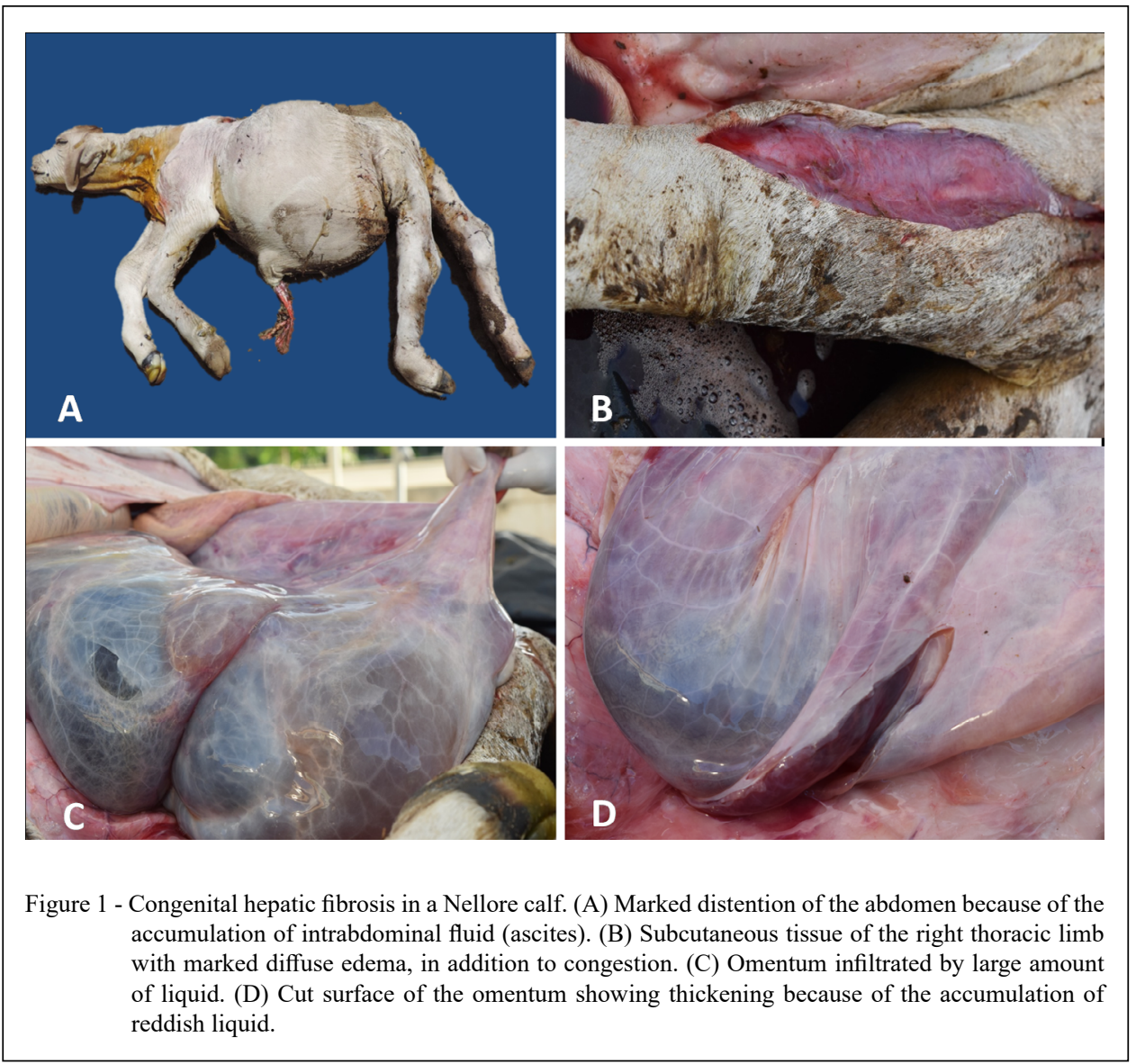

Ciência Rural, v.50, n.5, 2020. 
abundance of free, yellowish fluid in the thoracic cavity and pericardial sac. The liver was enlarged and had rounded edges, with an irregular capsular surface, due to the presence of extensive firm areas, interpreted as fibrosis. The mesenteric and limb lymph nodes were enlarged because of the accumulation of fluid.

Microscopically extensive areas of fibrosis were noted in the liver, mainly in the periportal areas with bile duct proliferation (Figure 2A). The fibrosis extended to other portions of the lobes, completely dissecting the hepatic parenchyma (port-portal fibrosis), with the formation of bridges, as evidenced by the special MT staining (Figure 2B). Lymph nodes distended the subcapsular sinuses, interpreted as intense lymphatic drainage, in addition to parenchyma necrosis and extramedullary hematopoiesis. In the lung, many alveoli were completely filled with yellowish material and flaking cells (meconium).

The diagnosis of congenital hepatic fibrosis syndrome in this stillborn calf was based on the characteristic changes of this condition, such as the large abdominal volume resulting from the abundant presence of fluid and liver fibrosis. Confirmation was made by histopathological evaluation and special MT staining, which allowed the evidence of intense periportal and port-portal fibrosis, associated with malformed bile ducts. This condition is rarely reported, and no previous report was reported in the Nellore breed. However, the literature associates this condition in other breeds with genetic disorders (TESTONI et al., 2009; BOURQUE et al., 2001).
The liver was large despite the extensive areas of parenchyma fibrosis, as evidenced by MT staining. Other authors have also reported this same aspect in calves with fibrosis of the liver and congenital ascites (BOURQUE et al., 2001; TESTONI et al., 2009). Unlike postnatal liver fibrosis, in which fibrosis invariably results in a reduced size liver (CULLEN \& STALKER, 2016). This indicated that the liver disease seen in congenital fibrosis results from a liver malformation and not from fibrosis resulting from previous organ damage, as seen in toxic and metabolic diseases (CULLEN \& STALKER, 2016). Therefore, in the present case, there is evidence that liver fibrosis was due to the failure of biliary tract development during fetal development.

Severe peritoneal and limb edema was a consequence of fibrosis of the liver parenchyma, as this lesion results in changes in hepatic blood flow and loss of organ function (INDART et al. 2019). Extensive diffuse liver fibrosis causes resistance to the passage of blood through the portal vein, and these results in hypertension with fluid transudation into the peritoneal cavity (ascites). This explains the observation of reddish color in the ascitic fluid of the calf in the present study. Conversely, in addition to the increase in vascular pressure, fluid transudation in the peritoneal cavity results from severe hypoalbuminemia, as there is an osmotic decrease in the colloid in the plasma. Albumin becomes low because of accelerated intestinal loss due to portal hypertension or because of reduced protein synthesis

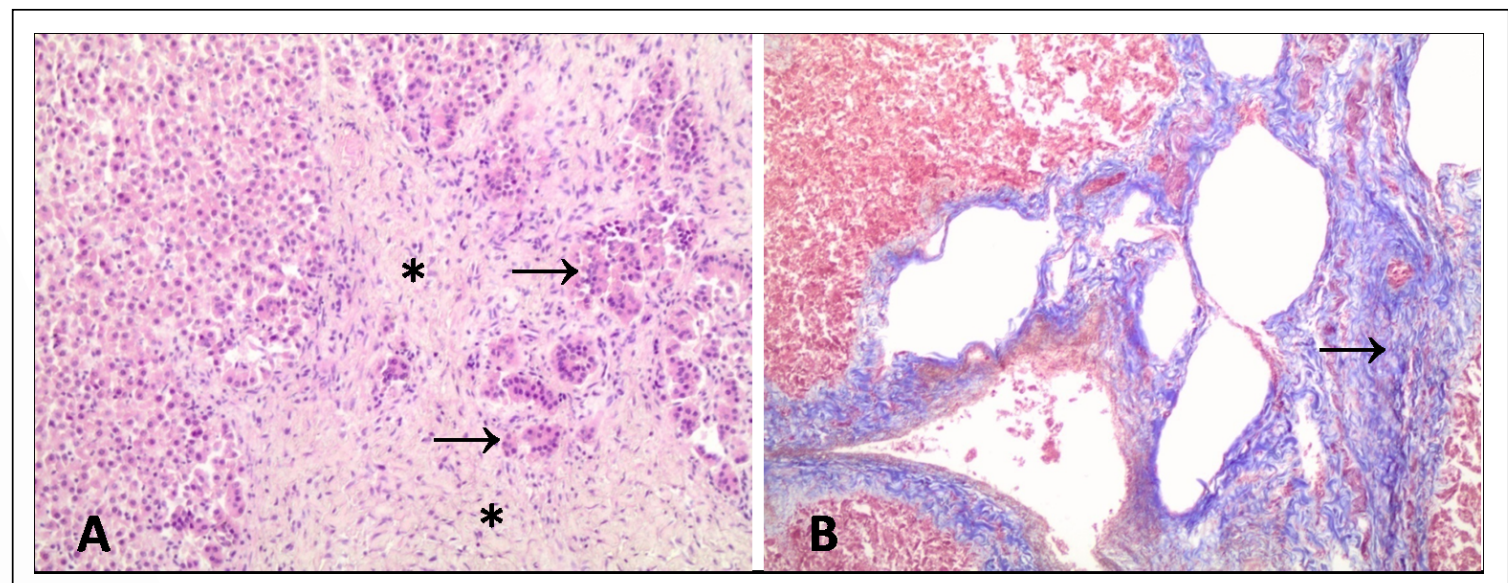

Figure 2 - Histopathological aspects of congenital hepatic fibrosis in the Nellore calf. (A) Liver showing extensive areas of fibrosis (asterisks), especially in the periportal area, with proliferation of malformed bile ducts (arrows), hematoxylin and eosin, 20× objective. (B) Extensive fibrosis of the liver parenchyma as evidenced by Masson's trichrome staining, 10× objective. 
by the injured liver (CULLEN \& STALKER, 2016). However, as the calf was already dead at birth; it was therefore, not possible to determine the degree of hypoalbuminemia.

In the histopathological evaluation of the lung, some alveoli had their lumen filled with yellowish material and flaking cells, thus characterizing the occurrence of meconium aspiration. Fetal hypoxia caused during dystocic delivery leads to bronchoaspiration. This hypoxia also causes relaxation of the anal sphincter with contamination of the amniotic fluid (LÓPEZ \& MARTINSON, 2013); thus, the animal aspirates amniotic fluid. The presence of fluid in the alveoli indicated that the calf died because of the long period in fetal distress and bronchoaspiration due to dystocia.

Dystocic delivery occurred due to the large abdominal volume presented by the edematous calf, causing the mother to remain in labor for many hours. Similar changes have been observed in other reports in cows of other breeds (TESTONI et al., 2009; BOURQUE et al., 2001). Therefore, research will be necessary to investigate genetic disorders, as well as the carriers of genes that can spread this condition in herds. Research involving the genealogical evaluation of animals affected by the disease in other countries has revealed that this condition originates from a single autosomal recessive gene locus (TESTONI et al., 2009). Thus, biomolecular testing of breeding cattle is necessary to detect the carriers of this gene locus.

Macroscopically, changes in the face must have Dexter-type chondrodysplasia (bulldog type) as their main differential diagnosis, since "bulldog calves" may also present ascites, but to a lesser extent than that observed in the calf in this report. In addition, the facial deformities observed in the calf were discrete compared with calves with chondrodysplasia (WURSTER et al., 2012), and no changes in growth cartilages were noted.

The marked congenital hepatic fibrosis was the determining factor for the development of ascites and limb edema. The marked abdominal distension, resulting from the accumulation of fluid, associated with limb hyperextension, favored dystocia, followed by fetal hypoxia and meconium aspiration that culminated in the death of the calf. This condition should be considered as an important differential diagnosis between the causes of dystocia in cattle in Brazil. Congenital fibrosis of the liver should be investigated in fetuses responsible for bovine dystocia since the reproducers carrying the genes for this condition cannot be kept in herds.

BIOETHICS AND
COMMITTEE APPROVAL

BIOSSECURITY

The authors of this article declared, for all due purposes, the project that gave rise to the present data of the same has not been submitted for evaluation to the Ethics Committee of the University/Research Institute "Universidade Federal da Paraíba", but we are aware of the content of the Brazilian resolutions of the National Council for Control of Animal Experimentation - CONCEA < http://www.mct.gov.br/index.php/ content/view/310553.html $>$ if it involves animals. This is a case report of a sick calf that was brought to Veterinary Pathology Laboratory-UFPB by the owner. Therefore, the diagnostic procedures were necessary and are part of the diagnostic routine. Thus, the authors assume full responsibility for the presented data and are available for possible questions, should they be required by the competent authorities.

\section{DECLARATION OF CONFLICT OF INTERESTS}

The authors declare no conflict of interest. The founding sponsors had no role in the design of the study; in the collection, analyses, or interpretation of data; in the writing of the manuscript, and in the decision to publish the results.

\section{ACKNOWLEDGEMENTS}

This research was also supported by National Council for Scientific and Technological Development $(\mathrm{CNPq})$, grant \#429862/2016-4, and was financed in part by the Coordenação de Aperfeiçoamento de Pessoal de Nível Superior (CAPES), Brasil Finance code 001

\section{AUTHORS CONTRIBUTIONS}

All authors critically revised the manuscript and approved the final version.

\section{REFERÊNCIAS}

AGERHOLM, J. S. et al. Familial chondrodysplasia in Holstein calves. Journal of Veterinary Diagnostic Investigation, Missouri, v.16, n.4, p.293-298, 2004. Available from: <https:// journals.sagepub.com/doi/pdf/10.1177/104063870401600406>. Accessed: Jun. 22, 2019.

BOURQUE, A. C. et al. Congenital hepatic fibrosis in calves. The Canadian Veterinary Journal, v.42, n.2, p.145146, 2001. Available from: <https://www.ncbi.nlm.nih.gov/ pubmed/9578757>. Accessed: Jun. 22, 2019.

HARPER, P. et al. Chondrodysplasia in Australian Dexter cattle. Australian Veterinary Journal, v.76, n.3, p.199-202, 1998. Available from: <https://www.researchgate.net/publication/316925251_Severe_ generalised chondrodysplasia in miniature cattle breeds/download $>$. Accessed from: Jun. 22, $201 \overline{9}$.

CULLEN, J. M.; STALKER, M. J. Liver and biliary system. MAXIE, M. G. Jubb, Kennedy, and Palmer's Pathology of Domestic Animals. v.3. $6^{\text {th }}$ ed. Philadelphia: Saunders Elsevier, 
2016, p.258-352.

INDART, M. et al. Congenital hepatic fibrosis in Holando Argentino calf: first report in Argentina. Brazilian Journal of Veterinary Pathology, v.12, n.2, p.58-62, 2019. Available from: <https:// bjvp.org.br/banner/2019/07/v-12-n-2-6-congenital-hepaticfibrosis-in-holandoargentino-calf-first-report-in-argentina/>. Accessed: Set. 15, 2019.

LÓPEZ, A.; MARTINSON, S. A. Sistema Respiratório, Mediastino e Pleuras. In: Zachary, J.F; McGavin, M.D. Bases da Patologia em Veterinária. Adaptado a realidade brasileira. Rio de Janeiro. Elsevier. 5ed. 2013. p.461-541.

MOVASSAGHI, A. R. et al. Congenital hepatic fibrosis in an aborted calf. Iranian Journal of Veterinary Research, Shiraz University, v.12, n.3, p.262-264, 2011. Available from: <http://ijvr.shirazu.ac.ir/article_76.html>. Accessed: Set. $15,2019$.

TESTONI, S. et al. Congenital facial deformities, ascites and hepatic fibrosis in Romagnola calves. Veterinary Record, v.164, n.22, p.693-69, 2009. Available from: <https:// veterinaryrecord.bmj.com/content/164/22/693>. Accessed: Jun. 22, 2019.

WURSTER, F. et al. Condrodisplasia tipo Dexter em fetos bovinos abortados. Acta Scientiae Veterinariae. v.40, n.3, p.2-3, 2012. Available from: $<$ http://www.redalyc.org/pdf/2890/289023557015. 